\title{
PENERAPAN MODEL PEMBELAJARAN KOOPERATIF TIPE SNOWBALL THROWING UNTUK MENINGKATKAN HASIL BELAJAR SISWA KONSEP SISTEM PERNAPASAN MANUSIA PADA KELAS XI SMA PGRI 1 AMBON
}

\author{
Friescilya Beatrix Latuperissa ${ }^{1}$, D. Rumahlatu ${ }^{2}$ \\ ${ }^{1}$ Alumni Program Studi Pendidikan Biologi \\ 2Dosen Program Studi Pendidikan Biologi \\ E-mail: dominggus_amq@yahoo.co.id
}

\begin{abstract}
Background: Education is defined as a process using certain models so that one can obtain knowledge, understanding, and ways of behaving according to needs. In this study aims to determine the effect of applying the snowball throwing learning model in improving learning outcomes on the concept of the human respiratory system in class XI SMA PGRI 1 Ambon

Method: This study was conducted from February 14 to March 14, 2018 in class XI SMA PGRI 1 Ambon.

Results: Through cooperative design shows that there is an increase in learning outcomes after using the snowball throwing model.

Conclusion: The application of the Snowball Throwing type cooperative learning model can improve the learning outcomes of the concept of human respiratory system in class XI IPA2 students of SMA PGRI 1 Ambon showing the level of success of students seen from cognitive, affective, psychomotor and final grades.
\end{abstract}

Keywords: Snowball throwing, learning outcomes, human respiratory system

\begin{abstract}
Abstrak
Latar Belakang: Pendidikan diartikan sebagai suatu proses dengan menggunakan model-model tertentu sehingga seseorang dapat memperoleh pengetahuan, pemahaman, dan cara bertingkah laku sesuai dengan kebutuhan. Dalam penelitian ini bertujuan untuk mengetahui pengaruh penerapan model pembelajaran snowball throwing dalam meningkatkan hasil belajar pada konsep sistem pernapasan manusia pada siswa kelas XI SMA PGRI 1 Ambon

Metode: Penelitian ini dilaksanakan dari tanggal 14 Februari - 14 Maret 2018 pada siswa kelas XI SMA PGRI 1 Ambon.

Hasil: Melalui desain kooperatif menunjukkan bahwa ada peningkatan hasil belajar setelah menggunakan model snowball throwing tersebut.

Kesimpulan: Penerapan model pembelajaran kooperatif tipe Snowball Throwing dapat meningkatkan hasil belajar konsep sistem pernapasan manusia pada siswa kelas XI IPA2 SMA PGRI 1 Ambon menunjukan tingkat keberhasilan siswa yang dilihat dari aspek kognitif, afektif, psikomotor serta nilai akhir.
\end{abstract}

Kata Kunci: Snowball Throwing, Hasil Belajar, Sistem Pernapasan Manusia 


\section{PENDAHULUAN}

Pendidikan diartikan sebagai suatu proses dengan menggunakan model-model tertentu sehingga seseorang dapat memperoleh pengetahuan, pemahaman, dan cara bertingkah laku sesuai dengan kebutuhan (Syah, 2010). Pendidikan diawali dengan proses belajar untuk mengetahui suatu hal kemudian mengolah informasi tersebut untuk diaplikasikan dalam kehidupan sehari-hari. Proses belajar tersebut tidak didapat secara instan melainkan melalui tahap-tahap yang pada akhirnya mencapai tujuan yang diharapkan.

Kualitas pendidikan tersebut tentu saja tidak terlepas dari proses belajar-mengajar siswa di sekolah. Proses belajar mengajar di kelas, guru sebagai ujung tombak dalam mencapai tujuanpembelajaran, guru harus memiliki metode atau model pembelajaran yang tepat agar siswa dapat belajar secara efektif dan efisien pada semua mata pelajaran termasuk mata pelajaran IPA. Pembelajaran dapat berlangsung secara baik apabila terjadi proses komunikasi dua arah yaitu antara pendidik dan siswa. Pemilihan model atau metode yang tepat akan membuat siswa merasa senang dalam menerima materi pembelajaran yang di sampaikan.

Menurut Suprijono (2009), model pembelajaran kooperatif tipe Snowball Throwing adalah suatu model pembelajaran yang diawali dengan pembentukan kelompok yang diwakili ketua kelompok untuk mendapat tugas dari guru kemudian masing-masing siswa membuat pertanyaan yang dibentuk seperti bola (kertas pertanyaan) lalu dilempar ke siswa lain yang masing- masing siswa menjawab pertanyaan dari bola yang diperoleh. Penerapan model pembelajaran kooperatif tipe Snowball Throwing membuat siswa lebih banyak berpartisipasi dalam mengikuti pembelajaran.

Pembelajaran kooperatif tipe Snowball Throwing (ST) ini lebih menekankan interaksi antar siswa.Pembelajaran dengan tipe ST merupakan salah satu modifikasi dari teknik bertanya yang menitik beratkan pada kemampuan merumuskan pertanyaan yang dikemas dalam sebuah permainan yang menarik yaitu saling melemparkan bola salju (ST) yang berisi pertanyaan kepada sesama teman sesuai dengan materi yang dipelajarinya (Ariyanto, 2011).

Hasil wawancara dengan salah satu guru biologi SMA PGRI 1 Ambon pembelajaran biologi masih belum optimal. Guru masih menyukai penggunaan metode ceramah dan Tanya jawab sehingga hasil belajar belum memuaskan hal ini terbukti pada nilai siswa tahun-tahun sebelumnya di bawah KKM, sehingga di perlukan model pembelajaran yang dapat mengaktifkan siswa seperti model pembelajaran kooperatif tipe Snowball Throwing untuk materi sistem pernapasan manusia. Proses pembelajaran tersebut kurang mendorong siswa untuk mengembangkan ketrampilan berpikir, akibatnya ketrampilan berpikir siswa kurang teraasa dengan baik.

Dengan inovasi model pembelajaran diharapkan dapat tercipta suasana belajar aktif, mempermudah penguasaan materi, peserta didik lebih kreatif dalam proses pembelajaran, kritis dalam menghadapi persoalan, sehingga dapat mencapai hasil pembelajaran yang lebih optimal. Agar tujuan pembelajaran yang terkandung di dalam kurikulum tersebut dapat tercapai dengan baik, maka guru pendidikan biologi di anjurkan agar secara kreatif menggunakan berbagai model pembelajaran yang dapat membantu proses analisis peserta didik.

\section{MATERIAL DAN METODE}

Penelitian ini merupakan penelitian deskriptif yang bertujuan untuk menggambarkan penerapan metode pembelajaran Snowball Tharowing untuk meningkatkan hasil belajar siswa konsep sistem pernapasan manusia pada kelas XI SMA PGRI 1 Ambon. Penelitian ini dilaksanakan di SMA PGRI 1 Ambon dari tanggal 14 Pebruari sampai dengan 14 Maret 2018.

Populasi yang digunakan dalam penelitian ini yaitu seluruh siswa kelas XI IPA SMA PGRI 1 Ambon yang berjumlah 96 siswa. Sampel dalam penelitian ini diambil secara acak yang terdiri dari 1 kelas yaitu kelas XI IPA1 dengan jumlah 26 siswa. Variabel yang digunakan dalam penelitian ini adalah variabel bebas yaitu pembelajaran dengan menggunakan metode pembelajaran Snowball Tharowing 
dan variabel terikat yang meliputi Peningkatan hasil belajar.

Data dalam penelitian ini diperoleh melalui tes awal dan tes formatif, dan observasi untuk mengamati kemampuan afektif dan psikomotor. Data kemampuan kognitif diperoleh lewat observasi pada LKS. Kemudian data diolah menggunakan analisis deskriptif:

1. Untuk mengukur pencapaian aspek kognitif, afektif, dan psikomotor.

Persentase jawaban siswa

$$
=\frac{\text { Jumlah skor yang diperoleh }}{\text { Skor maksimum }} \times 100
$$

2. Untuk mengukur nilai akhir (NA)

$\mathrm{NA}=\frac{6 \mathrm{P}+4 \mathrm{~F}}{10}$ (Menurut Arikunto, 2008)
Dengan

$\mathrm{P}=$ nilai proses

$\mathrm{F}=$ nilai formatif

\section{HASIL DAN PEMBAHASAN \\ Hasil \\ Tes Awal Siswa (Pre-Test)}

Hasil tes awal menggambarkan kemampuan awal siswa sebelum mengikuti proses belajar mengajar (KBM) materi pernapasan manusia dengan menerapkan Model Pembelajaran kooperatif tipe Snowball Throwing. Kualifikasi rata-rata skor pencapaian siswa pada tes awal terdapat pada Tabel 1 yang menunjukkan bahwa kemampuan awal siswa sangat rendah. Hal ini terbukti dengan 26 siswa $(100 \%)$ berada pada kategori kurang.

Tabel 1. Kualifikasi Skor Pencapaian Siswa Pada Tes Awal Tes

\begin{tabular}{cccc}
\hline Interval & Frekuensi & Presentase (\%) & Kualifikasi \\
\hline$\geq 70$ & - & - & Tuntas \\
\hline$\leq 70$ & 26 & $100 \%$ & Gagal \\
\hline Jumlah & 26 & $100 \%$ & - \\
\hline
\end{tabular}

Berdasarkan Pada Tabel 1 terlihat hasil pencapaian siswa pada tes awal, dimana pada interval $\geq 70$ tidak ada siswa yang memiliki nilai dengan kualifikasi tuntas, dan pada interval $\leq 70$ terdapat 26 siswa $(100 \%)$ berada pada kualifikasi kurang yang belum mampu menguasai indikator-indikator pembelajaran yang akan dipelajari. Sehingga dapat dikatakan ketuntasan belajar belum tercapai dengan rata-rata skor pencapaian 56,53 .

\section{Deskripsi Tingkat Penguasaan Siswa Selama Proses Pembelajaran}

Penilaian selama proses belajar mengajar dilaksanakan dengan berpatokan pada 3 aspek yaitu aspek kognitif, aspek afektif dan aspek psikomotor. Penilaian aspek kognitif dilakukan melalui lembar kerja siswa (LKS) sedangkan pada aspek afektif dan psikomotor merupakan penilaian langsung yang dilakukan selama proses belajar mengajar.

\section{Hasil kemampuan kognitif siswa}

Data kemampuan kognitif siswa selama proses pembelajaran dengan menerapkan Model Pembelajaran kooperatif tipe Snowball Throwing dapat dilihat melalui persentase LKS. Kualifikasi rata-rata skor pencapaian siswa pada LKS terlihat pada Tabel 2.

Tabel 2. Klasifikasi Penilaian Rerata Hasil Kognitif Pada Kelas Snowball Throwing

\begin{tabular}{cccc}
\hline \multirow{2}{*}{ Interval } & \multicolumn{2}{c}{ Kelas Snowball Throwing } & \multirow{2}{*}{ Kualifikasi } \\
\cline { 2 - 3 } & Frekuensi & Presentase (\%) & \\
\hline $91-100$ & - & & Sangat baik \\
$81-90$ & 20 & 76,92 & Baik \\
$70-80$ & 6 & 23,07 & $\begin{array}{c}\text { Cukup } \\
\text { Gagal }\end{array}$ \\
$<70$ & & & \\
\hline Jumlah & 26 & $100 \%$ & \\
\hline
\end{tabular}


Tabel 2 untuk kelas Snowball Throwing terdapat 20 siswa $(76,92 \%)$ memperoleh nilai pada interval (81-90) dengan klasifikasi baik, 6 siswa $(23,07 \%)$ memperoleh nilai pada interval (70-80) dengan klasifikasi cukup. Dengan demikian seluruh siswa pada kelas Snowball Throwing sudah menguasai indikator pembelajaran pada konsep sistem pernapasan manusia.

\section{Kemampuan afektif siswa}

Data mengenai kemampuan afektif siswa selama proses pembelajaran dengan menerapkan ditunjukkan Model Pembelajaran kooperatif tipe Snowball Throwing pada nilai unjuk kerja selama proses pembelajaran. Kualifikasi rata-rata skor pencapaian siswa pada aspek afektif dapat terlihat pada Tabel 3.

Tabel 3. Klasifikasi Penilaian Aspek Afektif Pada Kelas Snowball Throwing

\begin{tabular}{cccc}
\hline \multirow{2}{*}{ Interval } & \multicolumn{2}{c}{ Kelas Snowball Throwing } & \multirow{2}{*}{ Kualifikasi } \\
\cline { 2 - 3 } & Frekuensi & Presentase (\%) & \\
\hline $91-100$ & 2 & 7,69 & Sangat baik \\
$81-90$ & 20 & 76,92 & Baik \\
$70-80$ & 4 & 15,38 & $\begin{array}{c}\text { Cukup } \\
\text { Gagal }\end{array}$ \\
\hline 70 & & & \\
\hline Jumlah & 26 & $100 \%$ & \\
\hline
\end{tabular}

Berdasarkan Tabel 3 terlihat hasil pencapain siswa pada aspek afektif dimana pada interval terdapat 2 siswa $(7,69 \%)$ memperoleh nilai pada interval $(91$ $100)$ dengan klasifikasi sangat baik, 20 siswa $(76,92 \%)$ memperoleh nilai pada interval (81-90) dengan klasifikasi baik. 4 siswa $(15,38 \%)$ memperoleh nilai pada interval (70-80) dengan klasifikasi cukup. dibandingkan antara nilai KKM dengan rata rata skor pencapaian siswa pada aspek afektif, maka dapat dikatakan pencapaian afektif siswa berada pada kualifikasi tuntas.

\section{Kemampuan psikomotor siswa}

Data mengenai kemampuan Psikomotor siswa selama proses pembelajaran dengan menerapkan ditunjukkan Model Pembelajarankooperatif tipe Snowball Throwing. Kualifikasi rata-rata skor pencapaian siswa dapat dilihat pada tabel 4.

Tabel 4. Kualifikasi Hasil Belajar Siswa Pada Aspek Psikomotor

\begin{tabular}{cccc}
\hline \multirow{2}{*}{ Interval } & \multicolumn{2}{c}{ Kelas Snowball Throwing } & \multirow{2}{*}{ Kualifikasi } \\
\cline { 2 - 3 } & Frekuensi & Presentase (\%) & \\
\hline $91-100$ & 5 & 19,23 & Sangat baik \\
$81-90$ & 8 & 30,76 & Baik \\
$70-80$ & 13 & 50 & Cukup \\
$<70$ & & & Gagal \\
\hline Jumlah & 26 & $100 \%$ & \\
\hline
\end{tabular}

Berdasarkan tabel 4 terlihat hasil pencapaian siswa pada aspek psikomotor, dimana terdapat 5 siswa $(19,23 \%)$ memperoleh nilai pada interval (90-100) dengan klasifikasi sangat baik, 8 siswa $(30,76 \%)$ memperoleh nilai pada interval (71-85) dengan klasifikasi baik, dan 13 siswa (50) memperoleh nilai pada interval cukup Jika dibandingkan antara nilai KKM dengan rata-rata skor pencapaian siswa pada aspek psikomotor, maka dapat dikatakan pencapian psikomotor siswa berada pada kualifikasi tuntas.

\section{Hasil Tes Formatif (Post-Test)}

Data mengenai hasil skor pencapaian siswa dalam tes formatif Lampiran 18 yang dilaksanakan setelah kegiatan belajar mengajar dengan menerapkan Model Pembelajaran kooperatif tipe Snowball Throwing dapat dilihat pada tabel 4. 
Tabel 5. Kualifikasi Hasil Belajar Siswa Pada Tes Formatif

\begin{tabular}{cccc}
\hline \multirow{2}{*}{ Interval } & \multicolumn{2}{c}{ Kelas Snowball Throwing } & \multirow{2}{*}{ Kualifikasi } \\
\cline { 2 - 3 } & Frekuensi & Presentase (\%) & \\
\hline $91-100$ & 2 & 7,69 & Sangat baik \\
$81-90$ & 10 & 38,46 & Baik \\
$70-80$ & 14 & 53,84 & Cukup \\
$<70$ & & & Gagal \\
\hline Jumlah & 26 & $100 \%$ & \\
\hline
\end{tabular}

Berdasarkan tabel 5 dapat terlihat hasil pencapaian siswa pada tes formatif, dimana pada terdapat 2 siswa $(7,69 \%)$ memperoleh nilai pada interval (90-100) dengan klasifikasi sangat baik, 10 siswa $(38,46 \%)$ memperoleh nilai pada interval (81-90) dengan klasifikasi baik, Sedangkan 14 siswa $(53,84 \%)$ memperoleh nilai pada interval (70-80) dengan klasifikasi cukup. Dengan demikian seluruh sudah menguasai indikator pembelajaran pada konsep sistem pernapasan manusia.

\section{Deskripsi Nilai Akhir Siswa}

Setelah dilakukan pembelajaran dengan menerapkan Model Pembelajaran kooperatif tipe Snowball Throwing. pada materi sistem pernapasan manusia, pencapaian nilai akhir (NA) pada Lampiran 19 menggambarkan tingkat pencapaian penilaian afektif, psikomotor, kognitif serta pencapaian pada tes formatif dapat dilihat pada Tabel 6.

Tabel 6. Kualifikasi Hasil Belajar Siswa Pada Nilai Akhir

\begin{tabular}{cccc}
\hline \multirow{2}{*}{ Interval } & \multicolumn{2}{c}{ Kelas Snowball Throwing } & \multirow{2}{*}{ Kualifikasi } \\
\cline { 2 - 3 } & Frekuensi & Presentase (\%) & \\
\hline $91-100$ & 2 & 7,69 & Sangat baik \\
$81-90$ & 16 & 61,53 & Baik \\
$70-80$ & 8 & 30,76 & Cukup \\
$<70$ & & & Gagal \\
Jumlah & 26 & $100 \%$ & \\
\hline
\end{tabular}

Berdasarkan Tabel 6. terlihat hasil pencapaian siswa pada nilai akhir, dimana pada terdapat 2 siswa (7,69\%) memperoleh nilai pada interval (91-100) dengan klasifikasi sangat baik, 10 siswa $(38,46 \%)$ memperoleh nilai pada interval (81-90) dengan klasifikasi baik, dan 14 siswa $(53,84 \%)$ memperoleh nilai pada interval (70-80) dengan klasifikasi cukup.

\section{Pembahasan}

Dari hasil analisis tes awal menunjukan bahwa 26 siswa mendapat nilai dibawah KKM (70) Hal ini disebabkan karena materi pembelajaran belum pernah diajarkan dan setiap siswa memiliki kemampuan berpikir yang berbeda-beda. Tes awal (pre test) tes ini dilakukan dengan tujuan untuk mengetahui tingkat penguasaan siswa terhadap materi sebelumnya, untuk memberikan respon, motifasi// dorongan, dan menggali potensi siswa terhadap konsep yang diterima sebelumnya.Peningkatan terhadap hasil belajar perlu adanya model yang dapat mendukung proses pembelajaran, maka peneliti menerapkan suatu model yakni, model pembelajaran kooperatif tipe Snowball Throwing

Dalam proses pembelajaran ada 3 aspek penilaian yang dapat digunakan oleh guru dalam menilai kemampuan siswa. Menurut Bloom (2012) ketiga aspek itu antara lain aspek kognitif, afektif dan psikomotor. Aspek kognitif meliputi kemampuan berpikir, kompetensi memperoleh pengetahuan, pengenalan, pemahaman, konsep tualisasi, penentuan dan penalaran.Aspek Afektif meliputi sikap, nilai perasaan, emosi serta derajat penerimaan atau penolakan suatu objek dalam kegiatan belajar-mengajar. Aspek 
psikomotor merupakan kompetensi melakukan pekerjaan melibatkan anggota badan serta kompetensi yang berkaitan dengan gerakan fisik seperti refleks, keterampilan, gerakan dasar, kemampuan perseptual, ketepatan, keterampilan kompleks serta ekspresif dan interperatif (Santi Susanti, 2013) menyatakan bahwasiswa yang berkualitas adalah siswa yang bisa bersaing di dalam arti yang baik, di dalam persaingan diperlukan kualitas individu sehingga hasil karya atas produkproduk yang dihasilkan dapat berkompetensi, yang berarti mendorong kearah kualitas yang semakin lama semakin meningkat.

Dalam kegiatan belajar mengajar pada kelas snowball throwing telah memotivasi dan mendorong siswa untuk berusaha. Guru menyampaikan materi, siswa di bagi dalam 4 kelompok, masing-masing kelompok terdiri dari 6-7 orang dengan kemampuan yang berbeda-beda dan memanggil masing-masing ketua kelompok untuk memberikan penjelasan tentang materiketua-ketua kelompok kembali dan menjelaskan materi yang di sampaikan, kemudian masing-masing siswa di berikan LKS untuk menuliskan satu pertanyaan yang menyangkut materi yang telah di jelaskan oleh ketua kelompok.

Untuk menilai siswa dalam proses pembelajaran digunakan aspek kognitif, afektif dan psikomotor. Aspek kognitif dinilai dari hasil kerja LKS setiap kelompok.Setiap kelompok dapat menyelesaikan soal-soal yang terdapat pada LKS.Dilihat pada tabel 4 tentang presentase nilai kognitif (LKS), 26 siswa (100\%) berhasil mencapai ketuntasan belajar dengan kualifikasi yang berbedabeda. Aspek afektif dinilai dari faktor emosional pada siswa yang meliputi sikap jujur, rajin, partisipasi, penuh perhatian, kerjasama dan bertanggung jawab. Sedangkan Aspek psikomotor Menurut Simpson (2011) menyatakan bahwa hasil belajar ranah psikomotor tampak dalam ketrampilan (skill) dan kemampuan bertindak individu. Aspek psikomotor ini dinilai dari kegiatan-kegiatan motorik yang berhubungan dengan kemampuan intelektual yang meliputi Bahasa tubuh seperti kontak mata, postur dan gerakan tubuh yang digunakan secara aktif, Mendengarkan dengan aktif apa yang disampaikan oleh teman, Mendengar dan menerima dengan aktif penjelasan dari guru, Bertanya dengan menggunakan bahasa yang baik dan benar, menuliskan apa yang disampaikan oleh guru bertanya dengan menggunakan bahasa yang baik dan benar, menuliskan apa yang disampaikan oleh guru.

Setelah mengikuti proses belajar mengajar dengan menggunakan model pembelajaran kooperatif tipe snowball throwing maka dilakukan tes akhir (tes formatif). Penilaian formatif yang dilaksanakan bertujuan untuk mengetahui tingkat keberhasilan, baik dari sisi guru maupun sisi siswanya. Sedangkan menurut (Navel, 2012) Tes formatif, yaitu tes yang diberikan untuk memonitor kemajuan belajar selama proses pembelajaran berlangsung. Manfaat tes formatif bagi siswa adalah untuk mengetahui apakah siswa sudah menguasai materi dalam unit pembelajaran.

Pada tabel 5. hasil tes akhir (formatif) pada model pembelajaran snowball throwing menggambarkan bahwa 26 siswa (100\%) mampu mencapai nilai diatas KKM $(<70)$, dengan klasifikasi nilai yang berbeda-beda yaitu sangat baik, baik dan cukup. Hal ini menunjukan bahwa dalam model pembelajaran kooperatif tipe snowball throwing baik dan seluruh siswa mampu menguasai materi pembelajaran yang diajarkan dalam proses pembelajaran. Peningkatan hasil belajar ini karena siswa termotifasi untuk memperbaiki hasil tes awal yang diperoleh sebelum kegiatan belajar mengajar dimulai.

Hasil akhir siswa dalam kegiatan belajar mengajar (KBM) dapat digambarkan bahwa secara keseluruan siswa berhasil (tuntas). Menurut Mursel (2006) pembelajaran dikatakan berhasil dan berkualitas apabila seluruhnya atau setidaktidaknya sebagian besar peserta didik terlibat secara aktif, baik fisik, mental maupun social dalam proses pembelajaran. Pencapaian kompetensi siswa yang meliputi aspek kognitif siswa dari hasil penilaian proses kognitif dalam mengerjakan LKS, aspek afektif dan aspek psikomotor dalam lembaran penilaian serta hasil tes formatif dapat dilihat dari perolehan nilai akhir (NA) yang memuat tentang hasil pencapaian nilai akhir siswa 
yang di dapat dari penggabungan nilai yang di peroleh siswa tabel 6 . Menurut Morgan (2004) belajar dapat didefenisikan sebagai setiap perubahan tingkah laku yang relatif tetap dan terjadi sebagai hasil latihan dan pengalaman. Faktor-faktor belajar turut mempengaruhi hasil belajar siswa misalnya faktor kesiapan, minat, usaha dan lain-lain.

Berdasarkan hasil analisis nilai akhir siswa materi sistem pernapasan manusia dapat dilihat bahwa pada model pembelajaran kooperatif tipe snowball throwing mendapat nilai hasil belajar baikpada seluruh siswa Tabel 6 . terlihat hasil pencapaian siswa pada nilai akhir, dimana pada model kooperatif tipe snowball throwing terdapat 2 siswa $(7,69 \%)$ memperoleh nilai pada interval (91-100) dengan klasifikasi sangat baik, 10 siswa $(38,46 \%)$ memperoleh nilai pada interval (81-90) dengan klasifikasi baik, dan 14 siswa $(53,84 \%)$ memperoleh nilai pada interval (70-80) dengan klasifikasi cukup 11 siswa $(36,67 \%)$ Jadi dapat dikatakan bahwa model pembelajaran kooperatif tipe snowball throwing baik dan siswa mendapat nilai diatas KKM (70), jika dibandingkan dengan hasil dari tes awal yang dilakukan sebelum menerapkan model pembelajaran tersebut.

\section{KESIMPULAN}

Berdasarkan pembahasan mengenail hasil penelitian, dapat diambil kesimpulan sebagai berikut. Penerapan model pembelajaran kooperatif tipe Snowball Throwing dapat meningkatkan hasil belajar konsep sistem pernapasan manusia pada siswa kelas XI IPA2 SMA PGRI 1 Ambon menunjukan tingkat keberhasilan siswa yang dilihat dari aspek kognitif, afektif, psikomotor serta nilai akhir.

\section{DAFTAR PUSTAKA}

Arikunto, S. 2008. Dasar-dasar evaluasi pendidikan Jakarta Kencana

Ariyanto, A, 2013 Penerapan Cooperative Learning Tipe Snowball Throwing Untuk Meningkatkan Aktivitas Dan Hasil Belajar Ipa/Biologi Siswa Kelas Vii Smp Negeri 5 Metro T.P. 2011/2012. Universitas Riau No.1 Vol. 2 Hal 8-12
Bloom, 2012 Pengaruh Model Pembelajaran Snowball Throwing Terhadap Hasil Belajar Ipa Siswa Kelas $\checkmark$ Sd Di Gugus Sri Kandi Kecamatan Denpasar Timur Kencana prenada media group Jakarta persada Grafindo

Morgan, 2004. Peningkatan hasil belajar biologi pada materi kingdom animalia melalui penerapan model Teams tames Tournament dan Example non example. Bogor

Mursel, $2006 \quad$ Implementasi MetodeSnowball ThrowingUntuk Meningkatkan Hasil Belajar Fiqih Materi Binatang Halal Pada Siswa Kelas V Semester $1 \mathrm{Mi} \mathrm{Nu} 08$ Brangsong Kendal Tahun Pelajaran 2014/2015

Navel, 2012. Efektifitas model team game tournament berbantuan media kokami untuk meningkatkan hasil belajar ekonomi peran bank umum dan bank sentral. Universitas Negerisemarang

Syah, 2010 Pengaruh Penggunaan Model Pembelajaran Snowball Throwing Terhadap Aktivitas Belajar Dan Penguasaan Materi. Bandar lampung PT Raja grafindo persada

Simpson. 2011. Ilmu Teoritis dan Praktis, Bandung: PT. Remaja Rosdakarya

Suprijono, A. 2009. Cooperative Learning Teori dan Aplikasi Paikem. Yogyakarta: Pustaka Pelajar

Santi Susanti. 2013. Belajar dan faktorfaktor mempengaruhi, Jakarta: Rineka cipta. 